\title{
Medisch specialisten staan voor preventie
}

\section{Preventie prominent in visiedocument Medisch Specialist 2025}

\author{
Huib (H.A.) Cense
}

Published online: 11 February 2019

(c) The Author(s) 2019

De Federatie Medisch Specialisten heeft een toekomstvisie geformuleerd. Deze geeft richting aan de vraag hoe medisch specialisten hun rol en positie in de toekomst zien. Vier thema's staan centraal: de unieke patiënt en de moderne medisch specialist, richting netwerkgeneeskunde, betrokken bij gezondheid en gedrag, voorop in vernieuwing.

\section{Inleiding}

Het eerste thema, de veranderende relatie tussen arts en specialist, is al dagelijkse realiteit in de spreekkamer. De patiënt stelt meer vragen, de medisch specialist wil meer uitleg geven. De patiënt zoekt in de specialist steeds meer een coach, adviseur en begeleider. Deze ontwikkeling brengt ook andere bewegingen op gang. De medisch specialist wordt onderdeel van een team van zorgverleners dat steeds vaker samenwerkt in regionale zorgnetwerken: rondom de patiënt, dikwijls dichter bij huis, en met vervaging van de grenzen tussen eerste, tweede en derde lijn. In die netwerken neemt de aandacht voor preventie en innovatieve manieren van begeleiding toe - ook voor medisch specialisten een belangrijk thema. Nieuw is de aandacht voor preventie niet, de urgentie om erop te acteren wel. Dat is echt een verandering in de taakopvatting van de medisch specialist. Als een patiënt met een gebroken enkel bij de chirurg komt en die patiënt is ook 60 kilo te zwaar, dan vinden wij het de taak van de chirurg om daarvan iets te zeggen. En er iets mee te doen. Dat is geen paternalisme, maar voorlichting. Als we medisch specialisten ervan bewust weten te maken dat ze ook een preventieve taak hebben - bij indivi-

Dr. H. (H. A.) Cense ( $\square$ )

Federatie Medisch Specialisten, Utrecht, Nederland h.cense@demedischspecialist.nl duele patiënten en onder de algemene bevolking -, hebben we veel bereikt.

In dit artikel leest $\mathrm{u}$ de visie van de Federatie Medisch Specialisten op preventie zoals verwoord in het visiedocument Medisch Specialist 2025 [1].

'Niet alleen genezen maar ook voorkómen behoort tot de core business van ons vak'

Uiteraard is en blijft de belangrijkste taak voor medisch specialisten het behandelen van een patiënt met een aandoening of een ziekte. Zij kunnen echter ook bijdragen aan het bevorderen van gezondheid vanuit hun maatschappelijke verantwoordelijkheid als zorgprofessional. Verschillende ontwikkelingen zorgen ervoor dat er steeds meer aandacht is voor preventie en gezondheidsbevordering: demografische ontwikkelingen, de veranderende zorgvraag en de nieuwe definitie van gezondheid. Mede als gevolg van de toenemende prevalentie van chronische aandoeningen en multimorbiditeit wordt het 'bevorderen van gezondheid' steeds belangrijker. Niet voor niets hebben we in onze visie opgetekend dat medisch specialisten eraan bijdragen dat in 2025 minder mensen roken, minder alcohol drinken en meer bewegen. En dat ze zich in het openbaar en in de spreekkamer uitspreken over het belang van een gezonde Ze bieden op het gebied van preventie concrete handvatten aan hun patiënten. Dit doen zij op basis van een toegenomen kennis over de relatie tussen leefstijl, gezondheid, ziekte en functioneren, en over de effectiviteit van preventieve interventies.

\section{Steeds meer mogelijkheden om te focussen op gezondheidsbevordering}

De toename van inzichten in individuele risicofactoren voor (chronische) ziekten, bijvoorbeeld door 
DNA-onderzoek en Big Data, biedt mogelijkheden om zorg meer preventief in te richten. Hierdoor gaan we van ziektemanagement met een focus op behandelen naar risico- en gedragsmodificatie met een focus op voorkomen van ziekte en versterken van gezondheid. Het zal ook leiden tot nieuwe interventies of combinaties van interventies die gezondheidsrisico's kunnen verlagen.

\section{De medisch specialist als leefstijlcoach}

De medisch specialist heeft al vanuit de eed een rol bij preventie: 'Ik zal zorgen voor zieken, gezondheid bevorderen en lijden verlichten.' Medisch specialisten nemen deze verantwoordelijkheid door de risico's van een bepaalde leefstijl bespreekbaar te maken. Maar dat gesprek over leefstijl gaat niet vanzelf. Weliswaar achten medisch specialisten het bespreken van leefstijl in de spreekkamer van groot belang voor het behalen van een optimaal resultaat van een behandeling, in het dagelijks handelen blijkt dat preventie en gezondheidsbevordering nog onvoldoende zijn geïntegreerd. De inrichting van de Nederlandse gezondheidszorg in de gescheiden takken publieke, bedrijfsen curatieve gezondheidszorg, ondersteunt het integraal denken niet. Het is niet voor iedere medisch specialist duidelijk wat hij kan betekenen op het gebied van preventie en welke ideeën of producten er in andere disciplines worden ontwikkeld die inzetbaar en effectief kunnen zijn. Maar het is ook een mindset! Elke longarts zal een COPD-patiënt die rookt wijzen op de gevolgen van roken voor die ziekte, maar nog niet elke specialist brengt overgewicht ter sprake als de relatie met de klacht niet evident is.

\section{Preventie in 2025}

Binnen de curatieve gezondheidszorg verschillen de rol en mate van betrokkenheid van de medisch specialist bij preventie per specialisme, maar ook wat betreft de uiteenlopende soorten preventie: universele, selectieve, geïndiceerde en zorggerelateerde preventie.

Primair is de medisch specialist betrokken bij de geïndiceerde en zorggerelateerde preventie. Bij universele en selectieve preventie heeft de medisch specialist een meer adviserende en agenderende rol.

In 2025 is geïndiceerde preventie een actief thema in het gesprek met de patiënt, met als doel het tegengaan van ziekteprogressie of het ontstaan van chro- nische ziekten of bijkomende problematiek. De medisch specialist gaat met de patiënt in gesprek over de relatie tussen leefstijlfactoren en zijn gezondheid, en biedt zo mogelijk hulp bij het verbeteren hiervan. Dit betekent dat de specialist in 2025 actief handelt vanuit een holistisch mensbeeld en positieve gezondheid.

De mate van betrokkenheid is bij zorggerelateerde preventie het grootst. Deze rol is nu vaak al opgenomen in richtlijnen. In 2025 kijkt de medisch specialist steeds vaker samen met de patiënt hoe zij het functioneren van de patiënt optimaal kunnen herstellen, behouden of verbeteren.

\section{De agenda richting 2025}

De komende jaren worden kennis en bewustwording over de relatie tussen leefstijl, gezondheid, ziekte en functioneren bij patiënten en medisch specialisten vergroot. De reeds beschikbare kennis wordt op toegankelijke wijze gedeeld. Hierbij richt de specialist zich op positieve gezondheid, waarbij het functioneren en welbevinden (fysiek en psychisch) van de patiënt centraal staan, en biedt hij patiënten actief hulp op het gebied van preventie.

Het is aan individuele medisch specialisten, vakgroepen, medische staven en wetenschappelijke verenigingen om preventie binnen het eigen vakgebied actief te agenderen. En dat gebeurt al. In het land zie ik talloze collega's die zich inzetten om ziekte te voorkómen en te proberen roken, obesitas en alcoholgebruik terug te dringen. Bijvoorbeeld de wetenschappelijke vereniging van kinderartsen, die begin 2018 pleitte voor een verbod op energiedrank onder de achttien jaar, de wetenschappelijke verenigingen van longartsen, kinderartsen, cardiologen en gynaecologen, die de strijd aangaan met de tabaksindustrie, de oordoppenautomaat in de wachtkamer van knoartsen en kno-artsen in opleiding die leerlingen uit groep 8 voorlichting geven over gehoorschade als verplicht onderdeel van hun medisch-specialistische opleiding, en chirurgen die opiniestukken schrijven over het gevaar van obesitas. Medisch specialisten gaan letterlijk de spreekkamer uit en staan voor preventie.

\section{Literatuur}

1. Federatie Medisch Specialisten. Visiedocument Medisch Specialist 2025. Ambitie, vertrouwen, samenwerken. Utrecht: Federatie Medisch Specialisten; 2018. https:// www.demedischspecialist.nl/ms2025. 